\title{
Effect of Beverages on Bovine Dental Enamel Subjected to Erosive Challenge with Hydrochloric Acid
}

\author{
Dinah Ribeiro AMORAS ${ }^{1}$ \\ Silmara Aparecida Milori CORONA ${ }^{1}$ \\ Antonio Luiz RODRIGUES Jr${ }^{2}$ \\ Mônica Campos SERRA ${ }^{1}$
${ }^{1}$ Department of Restorative Dentistry, Ribeirão Preto Dental School, USP - University of São Paulo, Ribeirão Preto, SP, Brazil
${ }^{2}$ Department of Community Medicine, Ribeirão Preto Medical School, USP - University of São Paulo, Ribeirão Preto, SP, Brazil

\begin{abstract}
This study evaluated by an in vitro model the effect of beverages on dental enamel previously subjected to erosive challenge with hydrochloric acid. The factor under study was the type of beverage, in five levels: Sprite ${ }^{\circledR}$ Zero Low-calorie Soda Lime (positive control), Parmalat ${ }^{\circledR}$ ultra high temperature (UHT) milk, Ades ${ }^{\circledR}$ Original soymilk, Leão ${ }^{\circledR}$ Ice Tea Zero ready-to-drink low-calorie peach-flavored black tea and Prata ${ }^{\circledR}$ natural mineral water (negative control). Seventy-five bovine enamel specimens were distributed among the five types of beverages $(n=15)$, according to a randomized complete block design. For the formation of erosive wear lesions, the specimens were immersed in $10 \mathrm{~mL}$ aqueous solution of hydrochloric acid $0.01 \mathrm{M}$ for $2 \mathrm{~min}$. Subsequently, the specimens were immersed in 20 $\mathrm{mL}$ of the beverages for $1 \mathrm{~min}$, twice daily for 2 days at room temperature. In between, the specimens were kept in $20 \mathrm{~mL}$ of artificial saliva at $37^{\circ} \mathrm{C}$. The response variable was the quantitative enamel microhardness. ANOVA and Tukey's test showed highly significant differences $(\mathrm{p}<0.00001)$ in the enamel exposed to hydrochloric acid and beverages. The soft drink caused a significantly higher decrease in microhardness compared with the other beverages. The black tea caused a significantly higher reduction in microhardness than the mineral water, UHT milk and soymilk, but lower than the soft drink. Among the analyzed beverages, the soft drink and the black tea caused the most deleterious effects on dental enamel microhardness.
\end{abstract}

Key Words: dental enamel, tooth erosion. hydrochloric acid, in vitro study.

\section{INTRODUCTION}

Dental erosion or erosive tooth wear is a multifactorial condition $(1,2)$, characterized by the loss of hard tissue by chemical corrosion and dissolution by acids of non-bacterial origin (3). The origin of these acids is either extrinsic (dietary and environmental) or intrinsic (gastrointestinal) (4).

In the dental clinic, the lesions of dental erosion have been commonly found in patients with regurgitation (1), as in gastroesophageal reflux disease, or conditions with recurrent vomiting, such as anorexia and bulimia nervosa (5).

Frequent intake of acid beverages poses risk of erosion damage (6-8) in primary and permanent teeth (6).
Acid juices $(3,6)$, soft drinks and carbonated beverages show erosive effects (7). The chemical composition of a beverage is related to dental erosion (9) and contains citric acid, which is a strong chelator of tooth minerals and has been linked to the erosive effect of beverages $(7,10)$.

On the other hand, a content of calcium, phosphate and fluoride in beverages appears to be an important factor associated with potential erosion (7). Beverages enriched with calcium showed a decreased erosive potential (11) and an increased remineralizing capacity (12). However, the addition of varied and different calcium salts could not only modify the erosive potential, but also change the characteristics of original beverages such as flavor and color $(11,12)$. Promoting

Correspondence: Dinah Ribeiro Amoras, Departamento de Odontologia Restauradora, Faculdade de Odontologia de Ribeirão Preto, USP, Avenida do Café S/N, 14040-904 Ribeirão Preto, SP, Brasil. Tel/Fax: +55-16-3602-4103. email: dramoras@usp.br 
the consumption of milk or other beverages as natural sources of calcium could be a more effective and less costly preventive measure rather than supplementation with this mineral.

Calcium is an essential mineral for the structure of bones and teeth (13). The presence of phosphoproteins and calcium in the composition of cow milk could prevent enamel dissolution (14). Drinking milk after an erosive challenge could have a reparative effect on the remineralization of tooth enamel $(3,15)$.

The soybean extract, known as soymilk, presents calcium (13) and protein (16) in its composition. Soy products have attracted interest because of the health benefits attributed to the consumption of this legume (17).

Black tea contains fluoride in its composition (18). The presence of fluoride has beneficial effects on tooth enamel, increasing the resistance to acid dissolution (19).

The demineralization of the enamel surface could be reinforced by successive exposures of the oral environment to constant challenges of both intrinsic and extrinsic acids. Individuals with a history of diseases that involves vomiting or regurgitation may have a decreased microhardness of enamel surface, depending on the type of usually consumed beverages.

The aim of the present study was to evaluate by an in vitro experimental model the effect of beverages on the microhardness of dental enamel subjected to erosive challenge with hydrochloric acid $(\mathrm{HCl})$.

\section{MATERIAL AND METHODS}

\section{Experimental Design}

The studied factor was the type of beverage in five levels: Sprite ${ }^{\circledR}$ Zero Low-calorie Soda Lime (Companhia de Bebidas Ipiranga, Ribeirão Preto, SP, Brazil; positive control), Parmalat ${ }^{\circledR}$ ultra high temperature (UHT) integral cow milk (Companhia de Alimentos Glória, Votuporanga, SP, Brazil), Ades ${ }^{\circledR}$ Original soymilk (Unilever Brasil Alimentos Ltda., Pouso Alegre, MG, Brazil), Leão ${ }^{\circledR}$ Ice Tea Zero ready-to-drink low-calorie peach-flavored black tea (Companhia de Bebidas Ipiranga) and Prata ${ }^{\circledR}$ natural mineral water (Águas da Prata Ltda, Águas da Prata, SP, Brazil; negative control). The composition, $\mathrm{pH}$ and fluoride concentration of the beverages are given in Table 1.

The experiment used 75 bovine enamel specimens distributed among 5 types of beverages $(n=15)$, according to a randomized complete block design. The quantitative response variable was the microhardness (KHN) of enamel.

Table 1. Composition, $\mathrm{pH}$ and fluoride concentration of beverages.

\begin{tabular}{|c|c|c|c|}
\hline Beverages & Composition* & $\mathrm{pH}^{* *}$ & $\begin{array}{l}\text { Fluoride } \\
\text { concentration } * * * \\
(\mathrm{mg} / \mathrm{L})\end{array}$ \\
\hline $\begin{array}{l}\text { Sprite }^{\circledR} \text { Zero } \\
\text { Low-calorie Soda } \\
\text { Lime }\end{array}$ & $\begin{array}{l}\text { Carbonated water, lemon juice } 2.5 \% \text {, acidulant (citric acid), synthetic aroma } \\
\text { identical to the natural, artificial sweetener (sodium cyclamate and sodium } \\
\text { saccharin) }\end{array}$ & 2.91 & $<0.2$ \\
\hline $\begin{array}{l}\text { Leão }{ }^{\circledR} \text { Ice Tea } \\
\text { Zero ready-to- } \\
\text { drink low-calorie } \\
\text { peach-flavored } \\
\text { black tea }\end{array}$ & $\begin{array}{l}\text { Water, black tea extract, acidulant (citric and phosphoric acid), synthetic aroma } \\
\text { identical to the natural, conservatives ( sodium benzoate and potassium sorbate), } \\
\text { artificial sweetener (sodium cyclamate and sodium saccharin), sequestrant } \\
\text { (sodium hexametaphosphate), antifoam (dimethyl polysiloxane) }\end{array}$ & 3.02 & 0.760 \\
\hline Ades ${ }^{\circledR}$ Soymilk & $\begin{array}{l}\text { Soymilk, water, sugar, salt, vitamins (A, C, D, E, B2, B6, B12, folic acid), } \\
\text { minerals (calcium and zinc), vanilla flavor similar to the natural, stabilizers } \\
\text { (gum gellan, sodium citrate, xanthine gum and soy lecithin) }\end{array}$ & 7.35 & 0.265 \\
\hline $\begin{array}{l}\text { Prata }^{\circledR} \text { natural } \\
\text { mineral water }\end{array}$ & $\begin{array}{l}\text { Fluoridated radioactive mineral water, bicarbonate, sulfate, sodium fluoride, } \\
\text { sodium, potassium, magnesium, calcium, chloride, nitrate }\end{array}$ & 6.29 & 0.220 \\
\hline $\begin{array}{l}\text { Parmalat }{ }^{\circledR} \text { UHT } \\
\text { milk }\end{array}$ & $\begin{array}{l}\text { Standardized milk with } 3 \% \text { fat, stabilizers (sodium citrate, sodium triphosphate, } \\
\text { sodium monophosphate and diphosphate disodium) }\end{array}$ & 6.63 & $<0.2$ \\
\hline
\end{tabular}

*Composition compiled from data supplied by manufacturers on the product packaging. ** $\mathrm{pH}$ values measured with a $\mathrm{pH}$ meter. $* * *$ Fluoride concentration values $<0.2$ are below the sensitivity of the electrode. 


\section{Preparation of Enamel Specimens}

One hundred enamel slabs $(5 \times 4 \mathrm{~mm})$ were obtained from the coronal portion of 50 freshly extracted bovine incisors using a precision cutting machine (Isomet 1000; Buehler Ltd., Lake Bluff, IL, USA), and stored in $0.1 \%$ thymol solution at $4^{\circ} \mathrm{C}$. At the moment of use, slabs without fissure were embedded individually in epoxy resin (Epoxicure Resin, Buehler Ltd.) with the buccal enamel surface facing up. Grinding and polishing were performed onto 600- and 1200-grit aluminum oxide abrasive papers (Norton - Saint Gobain, São Paulo, SP, Brazil) in a water-cooled polishing machine (Beta Grinder-Polisher, Buehler Ltd.) and subsequently a 0.3 $\mu \mathrm{m}$ alumina suspension (Buehler Ltd.) was used with slight hand pressure only. Thereafter, the specimens were ultrasonically cleaned (Odontobrás Ind. e Com. Ltda., Ribeirão Preto, SP, Brazil) in deionized water for $10 \mathrm{~min}$ to remove any residues of the polishing procedures and immersed in artificial saliva.

\section{Initial Assessment and Selection of Specimens}

All 100 specimens were individually immersed in $20 \mathrm{~mL}$ of artificial saliva (20) for $48 \mathrm{~h}$ at $37^{\circ} \mathrm{C}$. Thereafter, Knoop microhardness indentations were made using a HMV-2 microhardness tester (Shimadzu, Kyoto, Japan). Three indentations ( $25 \mathrm{~g}$ for $30 \mathrm{~s}$ ) spaced $500 \mu \mathrm{m}$ apart were made at a distance of $500 \mu \mathrm{m}$ from the edge. After measurements, a total of 75 specimens were selected based on their higher average microhardness values.

\section{Lesion Formation of Erosive Wear}

The selected specimens had the buccal surface isolated except for a central circular area of about 5 $\mathrm{mm}^{2}$ before individual immersion in $10 \mathrm{~mL}$ of $0.01 \mathrm{M}$ $\mathrm{HCl}$ aqueous solution (21) for $2 \mathrm{~min}$. Subsequently, the specimens were washed with deionized water, immersed in artificial saliva (20) for $2 \mathrm{~h}$ at $37^{\circ} \mathrm{C}$, and then rinsed with deionized water and kept in relative humidity until Knoop microhardness readings.

\section{pH Measurement}

The $\mathrm{pH}$ of beverages was measured in a $\mathrm{pH}$ meter (model mPA 210; MS Tecnopon Piracicaba, SP, Brazil) connected to an electrode calibrated with standard solutions of $\mathrm{pH} 4.0$ and 7.0, respectively.

\section{Quantitative Analysis of Fluorides}

Determination of fluoride content the in solutions was performed using a selective electrode (Orion model 96-09) combined with ionic strength adjustment and $\mathrm{pH}$, using a $0.5 \mathrm{~mol} / \mathrm{L}$ citrate buffer, with $\mathrm{pH} 5.50$, ratio $1: 1$ sample/buffer. The concentration (x) was determined from the value of the obtained potential (y) and applied to the linear equation $\mathrm{y}=\mathrm{a}+\mathrm{b}$ $\log x$ using linear regression from the triplicate readings of suitably diluted standard fluoride solutions, where $a$ is the linear coefficient equation (slope) and $b$ is the angular coefficient. Calibration curve was obtained from the reading in $m V$ of a standard solution of sodium fluoride at $25^{\circ} \mathrm{C}$. Concentrations of sodium fluoride ranged from 0.2 to $1,000 \mathrm{mg} / \mathrm{L}$ (ppmF-).

\section{Immersion in Beverages}

The 75 previously eroded specimens were

*Homogeneity of variance with Bartlett test. Different letters indicate statistically significant difference within columns. 
randomly divided into 5 groups and subjected to immersion in the beverages ( 3 trial treatments and 2 control treatments), twice daily for 2 days at room temperature. The immersions were made under constant stirring in orbital shaker (CT155; Cientec, Piracicaba, SP, Brazil), at $50 \mathrm{rpm}$ speed for $1 \mathrm{~min}$ in a Becker tip recipient containing $20 \mathrm{~mL}$ of each beverage. The specimens remained individually immersed in $20 \mathrm{~mL}$ of artificial saliva (20) at $37^{\circ} \mathrm{C}$ in the intervals between the immersions in the beverages.

\section{Final Evaluation of Microhardness}

Final hardness of the specimens was measured using a HMV-2 microhardness tester (Shimadzu, Tokyo, Japan), performed after immersion in the beverages, with the same load and distance previously used for obtaining the initial microhardness readings, as well as after immersion in $\mathrm{HCl}$. Indentations were made parallel to the earlier measures.

\section{Statistical Analysis}

The homogeneity of variance in measures of initial hardness (initial KHN) and after challenge with $\mathrm{HCl}(\mathrm{KHN}$ after $\mathrm{HCl})$ was verified with the Bartlett test. Data from the initial hardness (initial KHN) and after challenge with $\mathrm{HCl}(\mathrm{KHN}$ after $\mathrm{HCl}$ ) were analyzed by one-way ANOVA, following the randomized complete block design. The effect of previously eroded enamel in the beverages was considered as the variable response difference measures observed between microhardness after immersion in beverages and the measures after challenge with $\mathrm{HCl}$. Tukey's test compared the effect of beverages. The softwares STATA version for windows (Stata Corporation, Houston, TX, USA) and R version 2.5.1 (R Foundation for Statistical Computing - General Public License, Boston, MA, USA) were used for statistical calculations in this study.

\section{RESULTS}

The Bartlett test showed homogeneity of variance in initial microhardness measurements of enamel specimens (initial $\mathrm{KHN}$ ) and after challenge with $\mathrm{HCl}$ (KHN after $\mathrm{HCl}$ ).

There was no significant differences of enamel microhardness among the 5 groups in the initial KHN $(\mathrm{p}=0.8403)$. There were also no significant differences among the microhardness values of the experimental groups after $\mathrm{HCl}$ challenge $(\mathrm{KHN}$ after $\mathrm{HCl})(\mathrm{p}=0.8761)$.

The differences between the enamel microhardness of specimens exposed to $\mathrm{HCl}$ and to the tested beverages were highly significant $(p<0.00001)$. The soda lime caused the greatest decrease in enamel microhardness, significantly higher than the other beverages. The exposure of enamel to low-calorie black tea caused a reduction of microhardness, significantly higher than the exposure to mineral water, soymilk and UHT milk, however less than the one caused by soda lime. There was no difference between cow milk, soymilk and mineral water, which did not cause further decrease of microhardness of enamel previously eroded with $\mathrm{HCl}$ (Table 2).

\section{DISCUSSION}

Chemical composition of an acidic beverage is clearly an important factor in the hardness properties of enamel (22). This study evaluated the effect of beverages on dental enamel submitted to erosive challenge with $\mathrm{HCl}$. The protocol used for the formation of erosion lesions was adapted from the in vitro model described by Messias et al. (23). In order to simulate the contact of the tooth surface with gastric contents resulting from gastric vomiting or reflux episodes, was used $0.01 \mathrm{M} \mathrm{HCl}$ (21) instead of orange juice. As $\mathrm{HCl}$ is a strong acid (24), the erosive challenge was set for a single immersion, using a shorter time ( $2 \mathrm{~min}$ instead of $5 \mathrm{~min}$ ) and a less acid solution $(10 \mathrm{~mL}$ instead of $20 \mathrm{~mL})$.

This study was developed using five commercially available beverages. Sprite Zero was used as the positive control because of its recognized erosive potential $(6,7)$. Cow milk was tested because it presents calcium and casein phosphoprotein $(14,15)$, which should protect enamel demineralization. The soymilk was included because it has calcium and protein in its composition $(13,16)$. Mineral water was used as the negative control because it has no erosive substances in its composition. The presence of fluoride in black tea composition (18) determined its inclusion, and its presentation as a ready-to-drink low-calorie tea was chosen because of its practicality. Analyzing the results of this study, Sprite Zero provided a significantly higher decrease in microhardness than the other beverages. A likely explanation for this fact could be the presence of citric acid and lemon juice in its composition and a 2.91 $\mathrm{pH}$ (below the critical). The chemical composition of 
a beverage is important to dental erosion (9). Citric acid is added to accentuate the lemon flavor, but it is a strong chelator of minerals and responsible for dental corrosion (10).

The black tea used in this study caused a reduction in microhardness significantly different than the mineral water, soy extract and UHT milk, but lower than the one caused by the soft drink. The presence of citric and phosphoric acids in the composition of the tested ice tea might have contributed to this result.

The presence of fluoride in black tea was measured by quantitative analysis demonstrated in a concentration of $0.760 \mathrm{mg} / \mathrm{L}$, which was unable to remineralize enamel previously subjected to erosive acid challenge with $\mathrm{HCl}$. Fluoride did not provide a protective effect on enamel when present in acidic carbonated beverages (25). The tested black tea contains fluoride, but other ingredients are also present in its composition, such as citric acid and phosphoric acid, which might have contributed to its negative result in terms of decrease of enamel microhardness.

In this study, UHT milk, soymilk and mineral water did not further decrease the surface microhardness of enamel subjected to erosive challenge with $\mathrm{HCl}$. Milk has considerable interest, due to its large consumption and its relation to tooth structure (14). The content of calcium and other minerals present in the composition of milk could promote enamel remineralization $(14,15)$. Milk showed no significant effect in remineralizing, a possible interpretation of this result could be the total exposure time, which was $4 \mathrm{~min}$. This might be an explanation for the fact that UHT milk and soymilk did not remineralize the enamel eroded by $\mathrm{HCl}$.

Under the conditions of this study, it may be concluded that Sprite Zero and Ice tea worsened the microhardness of dental enamel in a stronger manner compared with the other beverages. UHT milk, soymilk and mineral water did not decrease significantly surface microhardness nor were they able to remineralize the previously eroded enamel with $\mathrm{HCl}$. A reduction or replacement of beverages with potential in demineralizing tooth enamel would be an important factor in preventing damage in tooth structure, especially in individuals with disorders that involve contact with the $\mathrm{HCl}$ by regurgitation and vomiting.

\section{RESUMO}

Este estudo avaliou através de um modelo in vitro o efeito de bebidas no esmalte dental previamente submetido a desafio erosivo com ácido clorídrico. $\mathrm{O}$ fator em estudo foi o tipo de bebida, em cinco níveis: Sprite Zero (Coca-Cola ${ }^{\circledR}$ Brasil) controle positivo, leite integral Ultra High Temperature (Parmalat ${ }^{\mathbb{R}}$ ), extrato de soja integral (Ades ${ }^{\circledR}$ Original), chá preto com baixo teor calórico sabor pêssego (Leão Ice Tea Zero Coca-Cola ${ }^{\circledR}$ Brasil) e água mineral Prata $^{\circledR}$ (controle negativo). Setenta e cinco espécimes de esmalte bovino foram distribuídos entre os cinco tipos de bebidas $(n=15)$, de acordo com delineamento em blocos completos e casualizados. Para a formação das lesões de desgaste erosivo, os espécimes foram imersos durante $2 \mathrm{~min}$ em $10 \mathrm{~mL}$ de solução aquosa de ácido clorídrico $0,01 \mathrm{M}$. Subsequentemente foram imersos em $20 \mathrm{~mL}$ das bebidas por $1 \mathrm{~min}$, duas vezes ao dia durante 2 dias, em temperatura ambiente. Nos intervalos entre as imersões os espécimes permaneceram em saliva artificial a $37^{\circ} \mathrm{C}$. A variável de resposta quantitativa foi microdureza superficial do esmalte. ANOVA e teste de Tukey demonstraram diferenças altamente significativas $(p<0,00001)$ no esmalte exposto ao ácido clorídrico e às bebidas. O refrigerante provocou diminuição da microdureza superficial significativamente maior do que as demais bebidas. $\mathrm{O}$ chá preto provocou diminuição da microdureza significativamente maior que a água mineral, o leite UHT e o extrato de soja, porém menor que o refrigerante. Entre as bebidas analisadas, refrigerante e chá preto demonstraram efeitos mais deletérios sobre a microdureza do esmalte dental.

\section{ACKNOWLEDGEMENTS}

This manuscript is part of a dissertation submitted by the first author to the Ribeirão Preto Dental School, University of São Paulo, in partial fulfillment of the requirements for the Masters of Science degree in Restorative Dentistry. This study was supported by the Coordination for the Improvement of Higher Level Personnel (CAPES) and the National Council for Technological and Scientific Development (CNPq) (grants \#309219/2009-4 and \#504504/2010-0).

\section{REFERENCES}

1. Imfeld T. Dental erosion, definition classification and links. Eur J of Oral Sci 1996;104:151-155.

2. Lussi A, Jaeggi T. Erosion - diagnosis and risk factors. Clin Oral Investig 2008;12:5-13.

3. Amaechi BT, Higham SM. Dental erosion: possible approaches to prevention and control. J Dent 2005;33:243-252.

4. Lussi A, Jaeggi T, Schaffner M. Diet and dental erosion. Nutrition 2002;18:780-781.

5. Bartlett D. Intrinsic causes of erosion. Monogr Oral Sci 2006;20;119-139.

6. Lussi A, Kohler N, Zero D, Schaffner M, Megert B. A comparison of the erosive potential of different beverages in primary and permanent teeth using an in vitro model. Eur J Oral Sci 2000;108:110-114.

7. Lussi A, Jaeggi T, Zero D. The role of diet in the aetiology of dental erosion. Caries Res 2004;38:34-44.

8. Bartlett D. Etiology and prevention of acid erosion. Compend Edu Dent 2009;30:616-620.

9. Meurman JH, Frank RM. Progression and surface ultrastructure of in vitro caused erosive lesions in human and bovine enamel. Caries Res 1991;25:81-87. 
10. Young WG. Tooth wear: diet analysis and advice. Int Dent J 2005;55:68-72.

11. Lussi A. Dental erosion - Novel remineralizing agents in prevention or repair. Adv Dent Res 2009;21:13-16.

12. Hara AT, Zero DT. Analysis of the erosive potential of calciumcontaining acid beverages. Eur J Oral Sci 2008;116:60-65.

13. Pathomrungsiyounggul P, Grandison AS, Lewis MJ. Effects of calcium chloride and sodium hexametaphosphate on certain chemical and physical properties of soymilk. J Food Sci 2007;72:428-434.

14. Duarte PM, Coppi LC, Rosalen PL. Cariogenicity and cariostatic properties of different types of milk - review. Arch Latinoam Nutr 2000;50:113-120.

15. Gedalia I, Dakuar A, Shapira L, Lewinstein I, Goultschin J, Rahamim E. Enamel softening with Coca-Cola and rehardening with milk or saliva. Am J Dent 1991;4:120-122.

16. Jesudason $\mathrm{D}$, Clifton $\mathrm{P}$. The interaction between dietary protein and bone health. J Bone Miner Metab 2011;29:1-14.

17. Badger TM, Ronis MJJ, Hakkak R, Rowlands JC, Korourian $\mathrm{S}$. The health consequences of early soy consumption. J Nutri 2002;132:559-565.

18. Malinowska E, Inkielewicz I, Czarnowski W, Szefer P. Assessment of fluoride concentration and daily intake by human from tea and herbal infusions. Food Chem Toxicol 2008;46:1055-1051.

19. Simpson A, Shaw L, Smith AJ. The bio-availability of fluoride from black tea. J Dent 2001;29:15-21.

20. Amaechi BT, Higham SM, Edgar WM. Techniques for the production of dental eroded lesions in vitro. J Oral Rehabil 1999;26:97-102.

21. Hove L, Holme B, Øgaard B, Willumsen T, Tveit AB. The protective effect of $\mathrm{TiF}_{4}, \mathrm{SNF}_{2}$, and $\mathrm{NaF}$ on erosion of enamel by hydrochloric acid in vitro measured by white light interferometry. Caries Res 2006;40:440-443.

221. Machado C, Lacefield W, Catledge A. Human enamel nanohardness, elastic modulus and surface integrity after beverage contact. Braz Dent J 2008;19:68-72.

23. Messias DC, Martins ME, Serra MC, Turssi CP. Feasibility of using sodium bicarbonate as a damage-limiting strategy for erosion lesions. Oral Health Prev Dent 2008;6:155-158.

24. West NX, Hughes JA, Addy M. The effect of $\mathrm{pH}$ on the erosion of dentine and enamel by dietary acids in vitro. J Oral Rehabil 2001;28:860-864.

25. Larsen MJ, Richards A. Fluoride is unable to reduce dental erosion from soft drinks. Caries Research 2002;36:75-80.

Received March 3, 2012

Accepted May 22, 2012 